\title{
HORMONAL DISORDERS IN ADULT WOMEN WITH ACNE
}

\author{
BOGOMOLETS NATIONAL MEDICAL UNIVERSITY, Kyiv, Ukraine
}

M.D.Liudmyla Naumova, M.D.Lev Prystupiuk, M.D.Maksym Prystupiuk, M.D.PhD.Marianna Naumova, M.D.PhD.Oleksandr Prystupiuk

\section{INTRODUCTION}

UP TO 30\% OF WOMEN OF REPRODUCTIVE AGE SUFFER FROM ACNE. IN MOST CASES, ACNE LEADS TO DIFFERENT REPRODUCTIVE DISORDERS.

\section{THE PURPOSE OF THE STUDY}

TO DETERMINE THE FREQUENCY OF HORMONAL DISORDERS IN WOMEN WITH ACNE AND ACNE-SIMILAR CHANGES OF THE SKIN.

\section{RESULTS}

\begin{tabular}{|c|c|}
\hline \multicolumn{2}{|c|}{$\begin{array}{l}\text { Study women were found to have ovarian hyperandrogenism, } \\
\text { among different pathological conditions related to acne and acne- } \\
\text { similar rash with the following percentage: }\end{array}$} \\
\hline $\begin{array}{l}\text { Atypical (late) forms of congenital adrenal } \\
\text { dysfunction }\end{array}$ & $27 \%$ \\
\hline Polycystic ovarian syndrome & $20 \%$ \\
\hline Type 2 diabetes mellitus & $17 \%$ \\
\hline Hypothyroidism & $12 \%$ \\
\hline Hyperprolactinemia & $12 \%$ \\
\hline Early menopause & $10 \%$ \\
\hline Adrenal hyperandrogenism & $1 \%$ \\
\hline
\end{tabular}

\section{METHODS AND MATERIALS}

THE STUdy INVOLVED 30 FEMALE PATIENTS OF 18-55 YeAR OLD. EXAMINED WERE THEIR STATURE, THE SPREAD OF ACNE AND ITS PREDOMINANT LOCALIZATION, AND THE PRESENCE OF HIRSUTISM SYNDROME. AMONG MORPHOMETRIC PARAMETERS MEASURED WERE THE CIRCUMFERENCE OF WAIST AND HIPS WITH CALCULATION OF THE WAIST-HIP RATIO. BMI WAS DETERMINED AS WeLL. AlL PATIENTS WERE TESTED FOR VENOUS BLOOD GLUCOSE AND GLYCATED HEMOGLOBIN. HORMONAL EXAMINATION INCLUDED THE DETERMINATION OF FOLLOWING PARAMETERS: FREE TESTOSTERONE, PROLACTIN, THYROTROPIN, 17-OXYPROGESTERONE, DEHYDROEPIANDROSTERONE SULFATE, ESTROGEN, PROGESTERONE, STEROID-BINDING GLOBULIN, ANTI-MULLERIAN HORMONE.

SONOGRAPHY OF THYROID GLAND AND PELVIC ORGANS WAS ALSO PERFORMED.

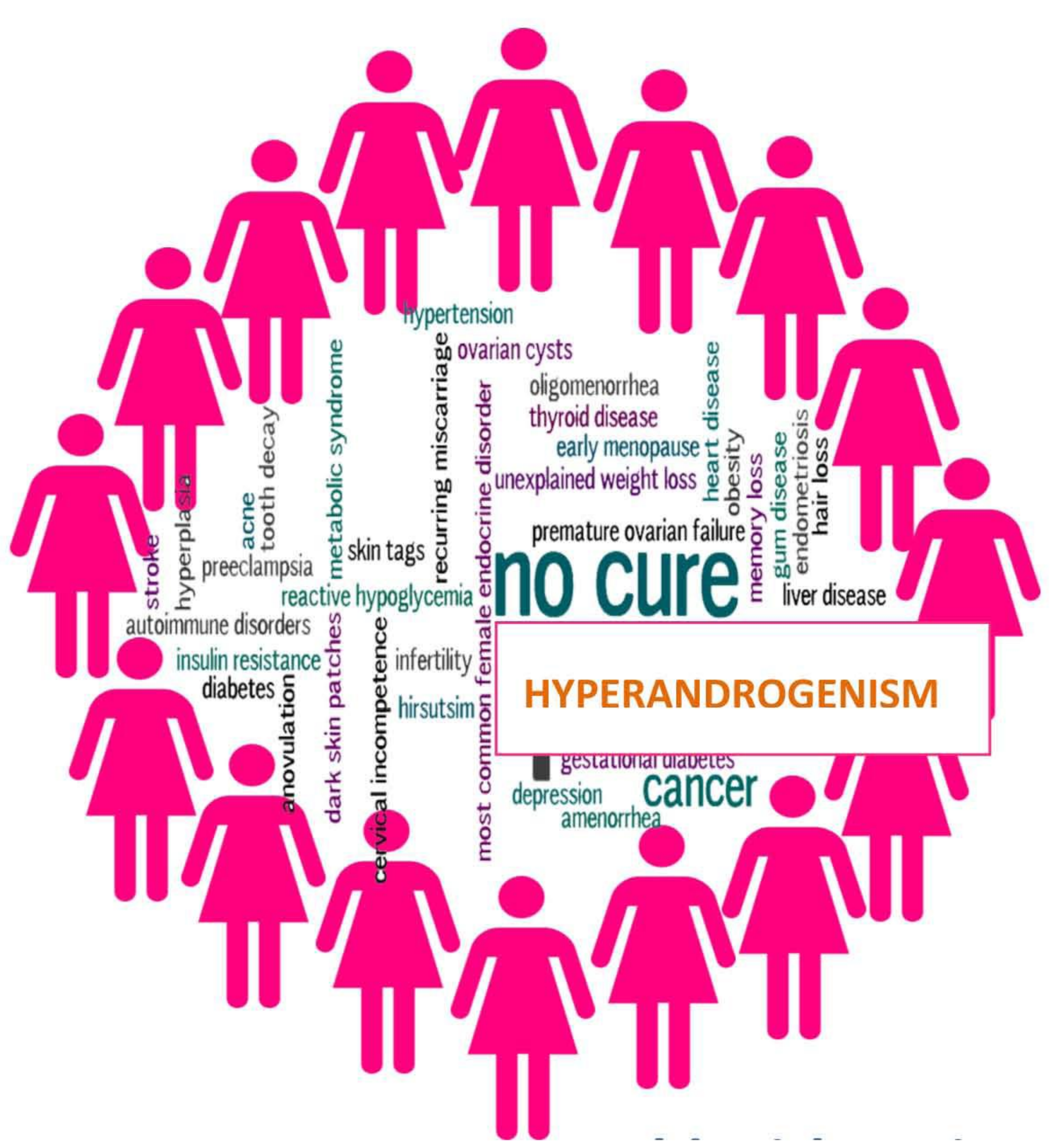

\section{CONCLUSIONS:}

THE BACKGROUND OF ACNE AND ACNE-SIMILAR RASH CHANGES IN WOMEN OF REPRODUCTIVE AGE ARE NUMEROUS HORMONAL AND METABOLIC CHANGES IN THE FEMALE ORGANISM. NOT ALL CASES OF ACNE ARE ACCOMPANIED WITH HYPERANDROGENISM. LOCAL TREATMENT OF ACNE IN WOMEN SHOULD BE PRECEDED BY INTENSIVE HORMONAL AND INSTRUMENTAL EXAMINATION OF WOMAN'S REPRODUCTIVE SYSTEM, AND DETERMINATION OF CARBOHYDRATE METABOLISM AND THYROID STATUS. 